\title{
Contribution to the Physico-Chemical Characterization of the Wastewater of Four Industrial Units of Preserve and Semi Fish Preserve of the City of Anza (North of
} Agadir)

\begin{abstract}
Slimani Noureddine, Hajji Sara
Laboratory of Aquatic Systems: Marine and continental ecosystems, Faculty of Sciences, Ibn Zohr University, Agadir, Morocco

\section{Hafid Naima}

Regional center for careers in education and training sous massa CRMEF-sm, Inezegane Morocco
\end{abstract}

\section{Moukrim Abdellatif}

Faculty of Sciences, Abdelamalek Essadi University, Tetouan, Morocco

\section{Zerbet Mohamed}

Laboratory LACAPE, Faculty of Sciences, Ibn Zohr University, Agadir, Morocco

\section{Ait Alla Aicha (Corresponding Author)}

Laboratory of Aquatic Systems: Marine and continental ecosystems, Faculty of Sciences, Ibn Zohr University, Agadir, Morocco. E-mail: a.aitalla@uiz.ac.ma

Received: Dec. 15, 2019 Accepted: Jan. 18, 2020 Published: Jan. 20, 2020

doi:10.5296/ast.v8i1.16307 URL: https://doi.org/10.5296/ast.v8i1.16037 


\section{Abstract}

The main objective of this study is to characterize the industrial wastewater of the city of Anza located north of Agadir in southwestern Morocco in order to recommend an adequate treatment allowing their reuse, thus reducing the nuisances that undergo the receiving environment (Anza Beach). This study concerns four industrial canned and semi-preserved fish plants that directly discharge their wastewater into the Anza beach. The physicochemical characterization of raw wastewater throughout 2017 revealed that these liquid discharges are heavily loaded with organic matter in terms of COD (Avg = $\left.10557 \mathrm{mg} \mathrm{O}_{2} / \mathrm{L}\right)$ and BOD $5\left(\mathrm{Avg}=4877 \mathrm{mg} \mathrm{O}_{2} / \mathrm{L}\right)$. ), in TSS (Avg $=3537 \mathrm{mg} / \mathrm{L}$ ) in mineral matter expressed in terms of chlorides (Avg $=25749 \mathrm{mg}$ / L), and in electrical conductivity $(\mathrm{Avg}=68957 \mu \mathrm{s} / \mathrm{cm})$ with a mean $\mathrm{pH}$ close to neutrality. The average levels of total nitrogen and total phosphorus are respectively of the order of 631 $\mathrm{mg} / \mathrm{L}$ and $84 \mathrm{mg} / \mathrm{L}$. Although these wastewaters have a high organic load (ratio BOD $/$ COD $=0.46$ and TSS $/ \mathrm{BOD}_{5}=0.72$ ), they have a satisfactory biodegradability. Examination of the $\mathrm{COD} / \mathrm{BOD}_{5}$ ratio of about 2.16 clearly underlines the biodegradability of the industrial wastewater studied. Biological treatment seems quite suitable.

Keywords: Anza, wastewater, industrial pollution, fish preserve, physico-chemical parameters

\section{Introduction}

The fight against environmental pollution has become a global concern. Increasingly important industrial discharges constitute a growing danger for the natural environment. They cause various alterations of the environment because of their suspended solids loads, dissolved substances often toxic (Bliefert \& Perraud, 2007; Sigg, Behra, \& Stumm, 2014). Recently, there has been an increase in the number of fish canneries around the world. Wastewater produced in this type of industry varies considerably depending on the production, the type of fish and the process used (Cristóvão et al., 2016). The main environmental problems related to canning fish is that it consumes a lot of water and produces huge volumes of liquid effluents rich in organic matter, oil and fat and salt. For the region of Anza (North of Agadir-Morocco), the industrial activity of canned and semi-preserved fish is one of these main economic resources. However, the liquid discharges discharged by its factories pollute more and more nature and constitute an increasing danger for the environment(Islam \& Tanaka, 2004). Almost all of the polluting industrial units located in Anza dump their industrial wastewater into the receiving environment without any prior treatment (Mimouni, Ait Alla, Anajjar, Finance, \& Moukrim, 2002).

The present work consists first of all to evaluate the effluents of four industrial canned and semi-conserved fish units within the industrial zone of the city of Anza and then to make a physico-chemical characterization by the determination of certain parameters major and global aspects of wastewater pollution in order to find a suitable means of treating these effluents. 
Table 1. Abbreviations and there meaning

\begin{tabular}{c|c}
\hline Abbreviations & Meaning \\
\hline $\mathrm{pH}$ & Hydrogen Potential \\
\hline COD & Chemical Oxygen Demand \\
\hline BOD5 & $\begin{array}{c}\text { Biochemical Oxygen } \\
\text { Demand }\end{array}$ \\
\hline TSS & Total Suspended Solids \\
\hline TN & Total Nitrogen \\
\hline TP & Total Phosphorus \\
\hline WWTP & Wastewater Treatment Plant \\
\hline TNK & Total Nitrogen Kjeldhal \\
\hline
\end{tabular}

\section{Materials and Methods}

\subsection{Study Site}

The industrial zone of Anza is located northwest of Agadir $4.5 \mathrm{~km}$ from the port of Agadir with a latitude and longitude of $30^{\circ} 25^{\prime} 12$ North and $-9^{\circ} 35^{\prime} 53$ West respectively. It covers an area of about 110 ha located along the coast between the port and Anza Urbain district. This zone is essentially characterized by the presence of agri-food units essentially linked to the processing of fishery products.

The existing sanitation infrastructure in the area consists of a unitary network that converges fully to a single point of discharge at the beach level. The direct discharge of sewage at the edge of the beach currently causes a very marked pollution of the littoral as well as a very important deterioration of the quality of the air (Ait Taleb, ElMaimouni, Laknifli, \& El Hammadi, 2010). Almost all the wastewater generated by this zone is of industrial type. This industrial wastewater is currently being discharged and dumped without treatment, posing a source of health risks and a threat to the coastline and bathing waters (Setti, Moukrim, Martinez-Urtaza, \& Hanoune, 2017).

The Figure 1 shows the points of discharge from the four industrial canned and semi-conserved fish units. 


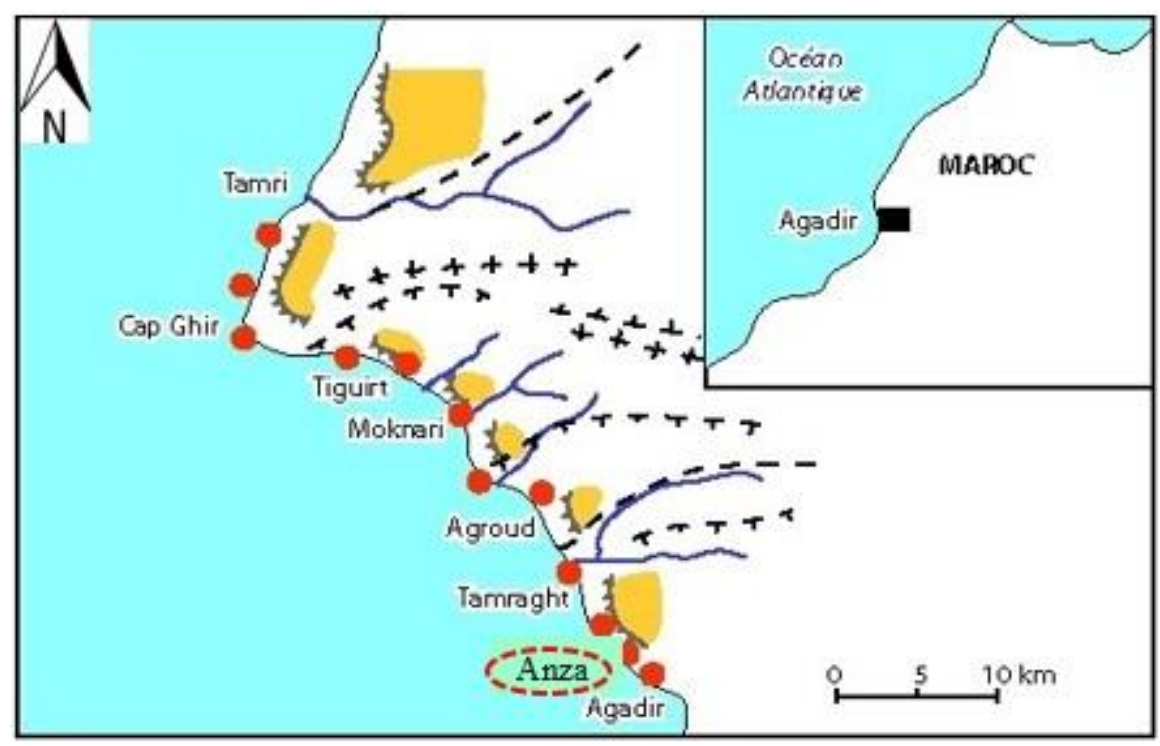

Figure 1. Geographical location of the study area

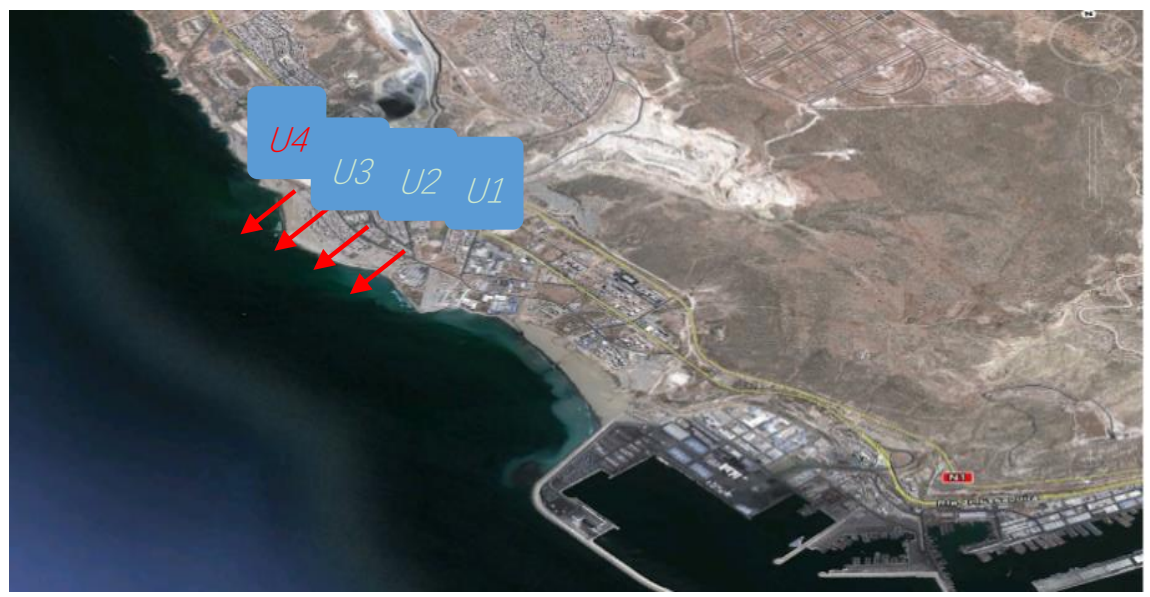

Figure 2. The wastewater discharge points of the four industrial units

\subsection{Identification of Sampling Points and Sampling Protocol}

Monitoring of the physico-chemical quality of industrial wastewater within the Anza area was carried out at the level of four industrial canned and semi-preserved fish units (U1, U2, U3 and U4). Table 2 summarizes data for these units: activity, annual production, water consumption, and wastewater discharge rates (RAMSA, 2004).

The data in Table 2 shows that the annual production of the four units varies from 2500 to 48500 t. Preserved and semi-preserved fish include sardines, mackerel and tuna. The number of permanent workers varies from 12 to 200 workers. All four units consume groundwater, the characteristics of which are presented in Table 3. Water consumption varies between 9277 $\mathrm{m}^{3} /$ year and $69000 \mathrm{~m}^{3} /$ year. The wastewater generated by the production activities is evacuated at different points. Their flow varies from $191 \mathrm{~m}^{3} / \mathrm{d}$ to $1200 \mathrm{~m}^{3} / \mathrm{d}$.

The wastewater sampling of the four industrial units was carried out during the year 2017 . 


\section{Macrothink Institute $^{\mathrm{TM}}$}

The samples were taken quarterly at the same dates for the four units: January 26, April 24, July 27 and October 23. These samples were taken at the discharge outlet of the industrial units in polyethylene bottles previously washed with distilled water. Samples are stored at low temperature $\left(4^{\circ} \mathrm{C}\right)$ in portable coolers and protected from light from the point of collection until arrival at the laboratory where there analyzes begin immediately. The conservation of wastewater samples has been done in accordance with the general guide for the conservation and handling of samples (Keith, 2017; Eymery, Choubert, Lepot, Gasperi, Lachenal, \& Coquery, 2012).

Table 2. Data on the four canned and semi-preserved industrial units

\begin{tabular}{|c|c|c|c|c|c|}
\hline & $\begin{array}{l}\text { Activity and production } \\
(\mathrm{t} / \text { year) }\end{array}$ & $\begin{array}{l}\text { Water consumption }\left(\mathrm{m}^{3}\right. \\
\text { / year) }\end{array}$ & $\begin{array}{l}\text { Waste water flow } \\
\text { discharged }\left(\mathrm{m}^{3} / \text { day }\right)\end{array}$ & Releases at sea & $\begin{array}{l}\text { Number of permanent } \\
\text { workers }\end{array}$ \\
\hline U1 & $\begin{array}{l}\text { Production of sardines, } \\
\text { mackerel and tuna: } \\
48500 t \text { / year. }\end{array}$ & $\begin{array}{l}69000 \mathrm{~m}^{3} / \text { year } \\
+4 \text { wells including } 2 \text { for } \\
\text { rescue }\end{array}$ & $438 \mathrm{~m}^{3}$ / day. & $\begin{array}{l}\text { Three points of } \\
\text { rejection }\end{array}$ & 826 permanents \\
\hline $\mathrm{U} 2$ & $\begin{array}{l}\text { Canned Fish } \\
2500 \mathrm{t} / \text { year }\end{array}$ & $\begin{array}{l}33652 \mathrm{~m}^{3} / \text { year } \\
+ \text { indeterminate well } \\
\text { water consumption }\end{array}$ & $191 \mathrm{~m}^{3} /$ day. & $\begin{array}{l}\text { Two points of } \\
\text { rejection }\end{array}$ & 120 permanents \\
\hline U3 & $\begin{array}{l}\text { Production of } \\
\text { semi-preserved } \\
\text { anchovies: } \\
\text { Se00t / year } \\
\text { Secondary activity: } \\
\text { peppers production } \\
(1,5 \mathrm{t} / \text { day). }\end{array}$ & $\begin{array}{l}9277 \mathrm{~m}^{3} \text { / year } \\
+ \text { water consumption of } \\
1 \text { indeterminate well. }\end{array}$ & $262 \mathrm{~m}^{3} / \mathrm{day}$ & $\begin{array}{l}\text { Two points of } \\
\text { rejection }\end{array}$ & $\begin{array}{l}12 \text { permanents } \\
201 \text { seasonal }\end{array}$ \\
\hline $\mathrm{U} 4$ & $\begin{array}{l}\text { canned sardines and } \\
\text { mackerel, Canned fish } \\
\text { (large): } \\
6250 \text { tone / year }\end{array}$ & $\begin{array}{l}36639 \mathrm{~m}^{3} \\
+ \text { water consumption of } \\
1 \text { indeterminate well. }\end{array}$ & $378 \mathrm{~m}^{3} /$ day & $\begin{array}{l}1 \text { point of } \\
\text { rejection }\end{array}$ & $\begin{array}{l}28 \text { permanents } \\
350 \text { seasonals }\end{array}$ \\
\hline
\end{tabular}


Table 3. Characteristics of the groundwater used in the industrial area

\begin{tabular}{l|c}
\hline \multicolumn{1}{c|}{ Parameters } & Mean Values \\
\hline $\mathrm{T}^{\circ} \mathrm{C}$ & 23,45 \\
\hline $\mathrm{pH}$ & 7,635 \\
\hline Turbidity NTU & 1,035 \\
\hline Conductivity $(\mu \mathrm{s} / \mathrm{cm})$ & 2815 \\
\hline $\mathrm{TSS}(\mathrm{mg} / \mathrm{L})$ & 2 \\
\hline $\mathrm{COD}(\mathrm{mg} / \mathrm{L})$ & 0 \\
\hline BOD5 $(\mathrm{mg} / \mathrm{L})$ & 0 \\
\hline Bicarbonates $(\mathrm{mg} / \mathrm{L})$ & 236 \\
\hline Ammonium $(\mathrm{mg} / \mathrm{L})$ & $<0,02$ \\
\hline Nitrites $(\mathrm{mg} / \mathrm{L})$ & $<0,02$ \\
\hline Nitrates $(\mathrm{mg} / \mathrm{L})$ & 19,425 \\
\hline TNK $(\mathrm{mg} / \mathrm{L})$ & 3 \\
\hline total Phosphorus $(\mathrm{mg} / \mathrm{L})$ & 0,155 \\
\hline Orthophosphate $(\mathrm{mg} / \mathrm{L})$ & 0,055 \\
\hline Sodium $(\mathrm{mg} / \mathrm{L})$ & 217,5 \\
\hline Potassium $(\mathrm{mg} / \mathrm{L})$ & 4,875 \\
\hline Chlorides $(\mathrm{mg} / \mathrm{L})$ & 819,5 \\
\hline Sulfates $(\mathrm{mg} / \mathrm{L})$ & 59,5 \\
\hline KMno4 Organic Matter & 1,06 \\
\hline Magnesium $(\mathrm{mg} / \mathrm{L})$ & 50 \\
\hline Calcium $(\mathrm{mg} / \mathrm{L})$ & 137,5 \\
\hline
\end{tabular}

\subsection{Analytical Methods}

\subsection{1 pH, Electrical Conductivity and Temperature}

The hydrogen potential $(\mathrm{pH})$, the electrical conductivity and the temperature were measured in situ using a multipara meter Type ORION STAR A329.

\subsubsection{COD and $\mathrm{BOD}_{5}$}

COD was determined according to ISO 15705 (ISO, 2002). The measurements were made by C24 /25 (WTW) COD tube test heated for 120 minutes at $148{ }^{\circ} \mathrm{C}$ in a preheated thermoreactor and then measured in a HACH DR3900 spectrophotometer (J Rodier, Legube, Merlet, \& Brunet, 2009). For BOD 5 , the amount of oxygen consumed by the sample is proportional to the concentration of oxidizable materials (Jean Rodier \& Legube, 2009). The measurements were carried out using a BOD-meter type OxiTOP - WTW. 


\subsubsection{Suspended Solids}

The suspended solids were determined according to the AFNOR standard (NF T90-105-2) (Dramais, Camenen, \& Le Coz, 2018). After filtration of a test sample on Wathman GF / C filters $(0.45 \mu \mathrm{m})$, the mass of the retained materials is determined by differential weighing. The filters are placed in an oven at $105^{\circ} \mathrm{C}$ for 2 hours and weighed.

\subsubsection{Total Nitrogen and Total Phosphorus}

The nitrogen contained in the filtered sample is oxidized to nitrates which are then reduced to nitrite in the medium and form a compound whose absorbance at $540 \mathrm{~nm}$ is proportional to the concentration of nitrite ions (Nelson \& Sommers, 1973). Total phosphorus (TP) is a cumulative parameter that includes organic and inorganic phosphorus compounds. It was analyzed according to the AFNOR standard (NF T 90-023) (Ebina, Tsutsui, \& Shirai, 1983). The different forms of phosphorus are thus transformed into orthophosphate $\left(\mathrm{PO}_{4}\right)$.

\subsubsection{Chlorides}

The chlorides are determined according to the method of Mohr, in neutral medium by titrated solution of silver nitrate in the presence of potassium chromate. The end of the reaction is indicated by the appearance of the characteristic red hue of silver chromate (Korkmaz, 2001).

\subsubsection{Oil and Grease}

Determination of the concentration of total oils and fats was done mainly in two stages. The total oils and fats contained in the sample are first extracted with hexane. This extract was then evaporated to dryness and weighed to determine the concentration of total oils and fats by gravimetry (Romero \& Ferrer, 1999).

\section{Results and Discussion}

The physico-chemical quality of wastewater produced by canning fish is highly variable. It varies according to several parameters, including the production season, the type of fish processed, the additives used, the source of process water and the processes used (Cristovão, Botelho, Martins, \& Boaventura, 2012). The physico-chemical analyzes of wastewater from the four industrial units concerned the parameters: Temperature, $\mathrm{pH}$, electrical conductivity, TSS, COD, BOD5, total nitrogen, total phosphorus, chlorides and oils and fats. Wastewater collected has a gray color and its odor is bad. The results obtained are presented below.

\subsection{T, $p H$ and $C E$}

\subsubsection{Water Temperature}

The temperature of a wastewater plays a very important role in the solubility of salts and especially gases. This physical quantity makes it possible to detect extreme conditions that are detrimental to the proper functioning of the biological process.

Figure 3 shows the wastewater temperature measurements of the four industrial units. The industrial units $\mathrm{U} 2, \mathrm{U} 3$ and $\mathrm{U} 4$ have temperatures that range between 22.7 and $28.9^{\circ} \mathrm{C}$. On the other hand, the U1 unit has high temperatures compared to the other units studied and 


\section{Macrothink}

which vary between 21.3 and $26^{\circ} \mathrm{C}$. The values of the temperature of the discharges of the canned and semi-preserved units are therefore all lower than the limit value of $30{ }^{\circ} \mathrm{C}$ fixed by the Moroccan norm of direct discharge V(LDD) (Morocco's Official Gazette, $\mathrm{N}^{\circ}$. 5062, the standards of direct and indirect discharges, 2002).

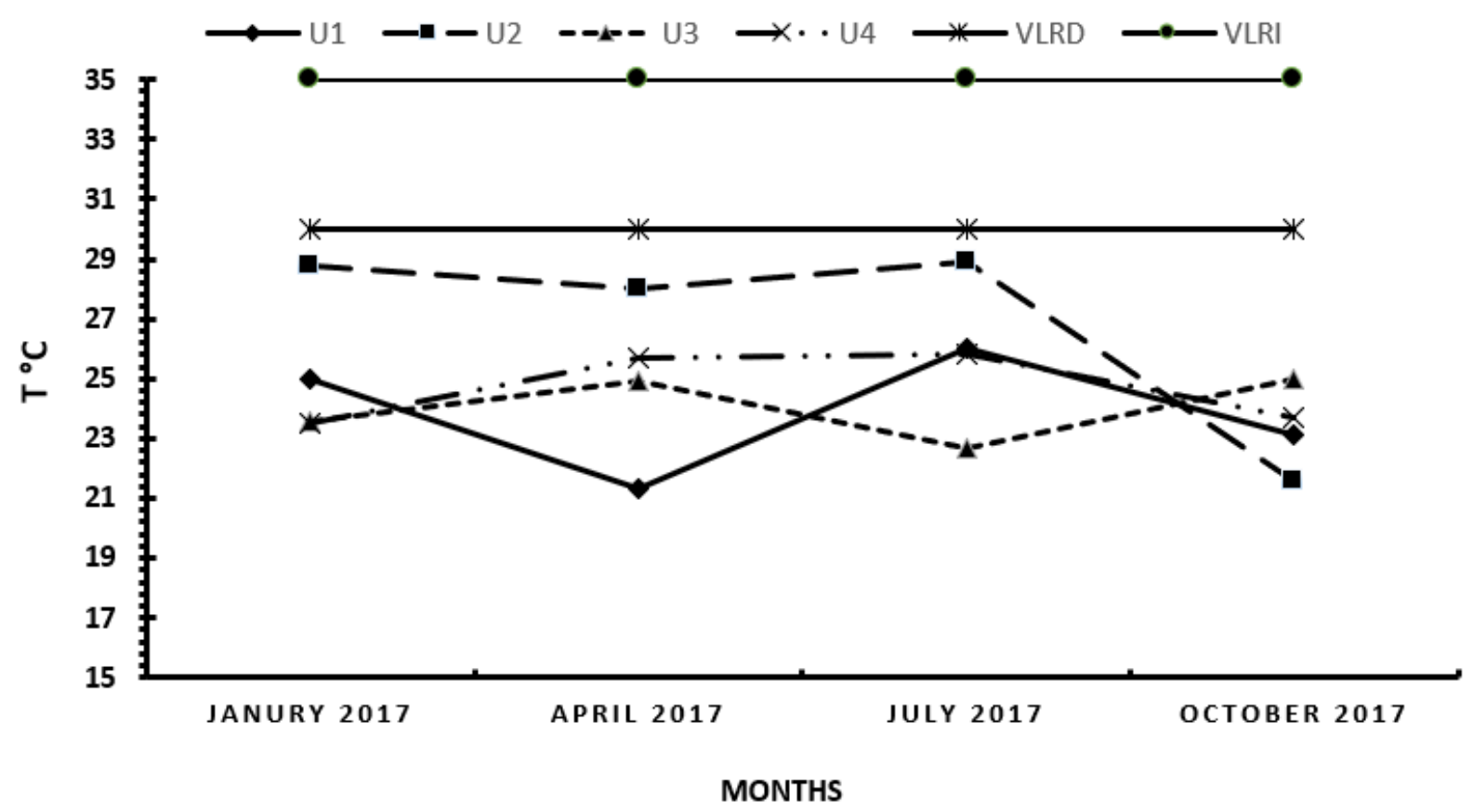

Figure 3. Temperature variation of the four releases studied

\subsubsection{Hydrogen Potential $(\mathrm{pH})$}

In general, the $\mathrm{pH}$ for the biological activity is between 6.5 and 8.5. Outside this range, the $\mathrm{pH}$ affects the aquatic life and consequently influences the self-purification of the natural environment. It is also an important element for the interpretation of corrosion in the pipelines of purification plants. Figure 4 shows the quarterly evolution of the $\mathrm{pH}$.

The $\mathrm{pH}$ variations for the four industrial units are almost similar and vary between 6.01 and 8.32. The seasons of the year have no impact on $\mathrm{pH}$ because this variation is directly related to production. They are comparable to those reported by Benyakhlef, Naji and Belghyti (Benyakhlef, Naji, \& Belghyti, 2007). The average values remain close to the neutrality figure 4 . With the exception of the unit 2 where values lower than 6.5 were recorded, all the other $\mathrm{pH}$ values are between 6.5 and 8.5 considered to be compliant with the Moroccan standard for direct discharges into the natural environment (Morocco's Official Gazette, $\mathrm{N}^{\circ}$. 5062, the standards of direct and indirect discharges, 2002). 


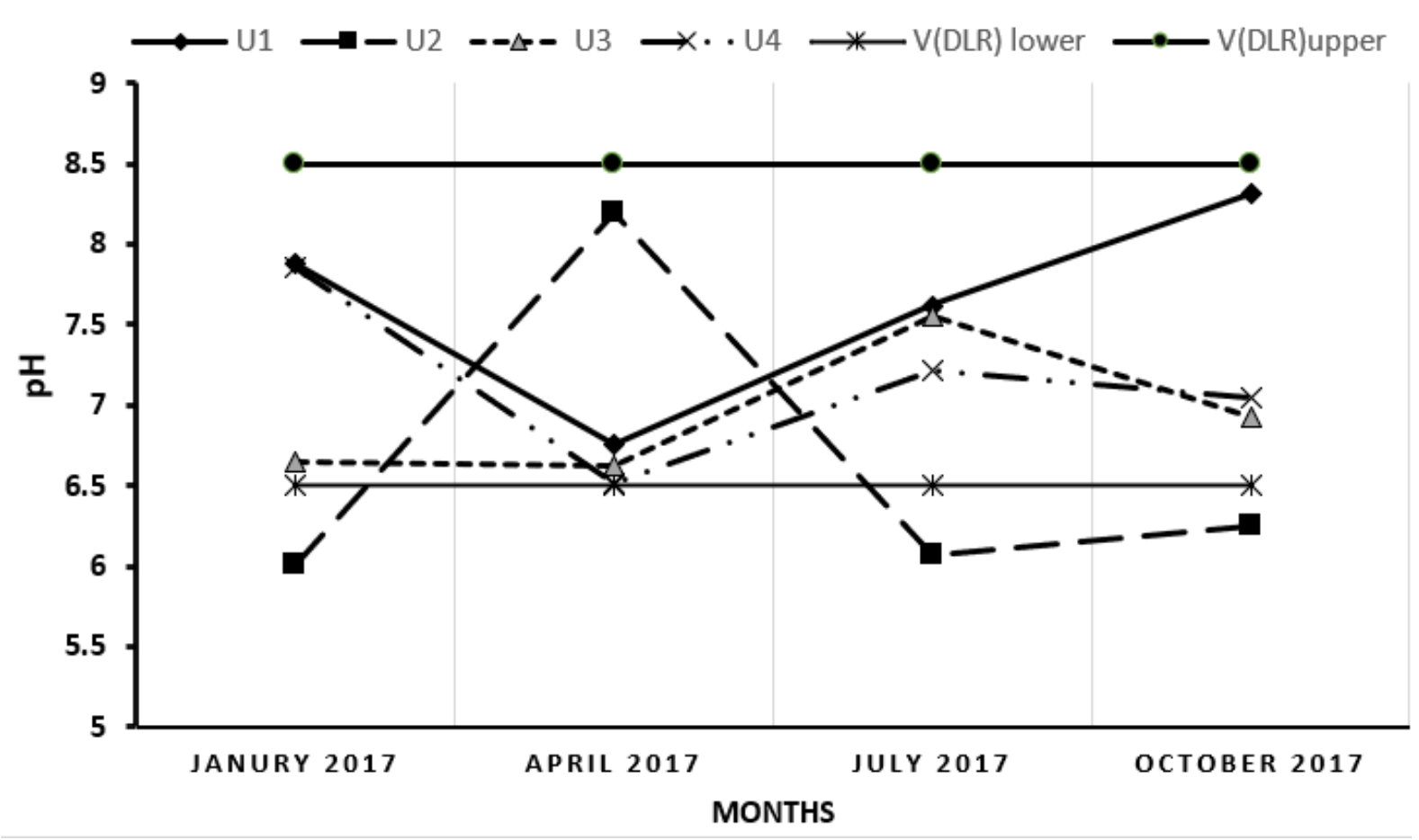

Figure 4. $\mathrm{pH}$ variations of the four releases studied

\subsubsection{Electrical Conductivity (CE)}

As in most processing industries, seafood processing activities produce wastewater containing soluble contaminants. The degree of contamination depends on several factors (Colic, Morse, Hicks, Lechter, \& Miller, 2007). Figure 5 shows the variations of the electrical conductivity of the studied wastewater. Electrical conductivity provides information on the degree of overall mineralization of the water. High conductivity indicates either abnormal $\mathrm{pH}$ values or, in most cases, high salinity, which may be natural or due to saline discharges (Lefebvre \& Moletta, 2006). Based on the monitoring and analysis of electrical conductivity at the four sampling units, remarkable variations in this parameter were noted (Figure 5). The average values recorded are between $20150 \mu \mathrm{S} / \mathrm{cm}$ as the minimum value recorded in January at the level of unit 1 and $151900 \mu \mathrm{S} / \mathrm{cm}$ recorded at unit 3 . These values reflect a high mineralization of these wastewaters. The processing activity of fishery products is at the base of brine baths. The overall average is $56637 \mu \mathrm{S} / \mathrm{cm}$. These values are well above the limits imposed by Moroccan regulations (Morocco's Official Gazette, $N^{\circ}$. 5062, the standards of direct and indirect discharges, 2002). They are also higher than those measured in 2017 at the level of another fish cannery in the Anza industrial zone (Al-Juhaishi, 2018). 


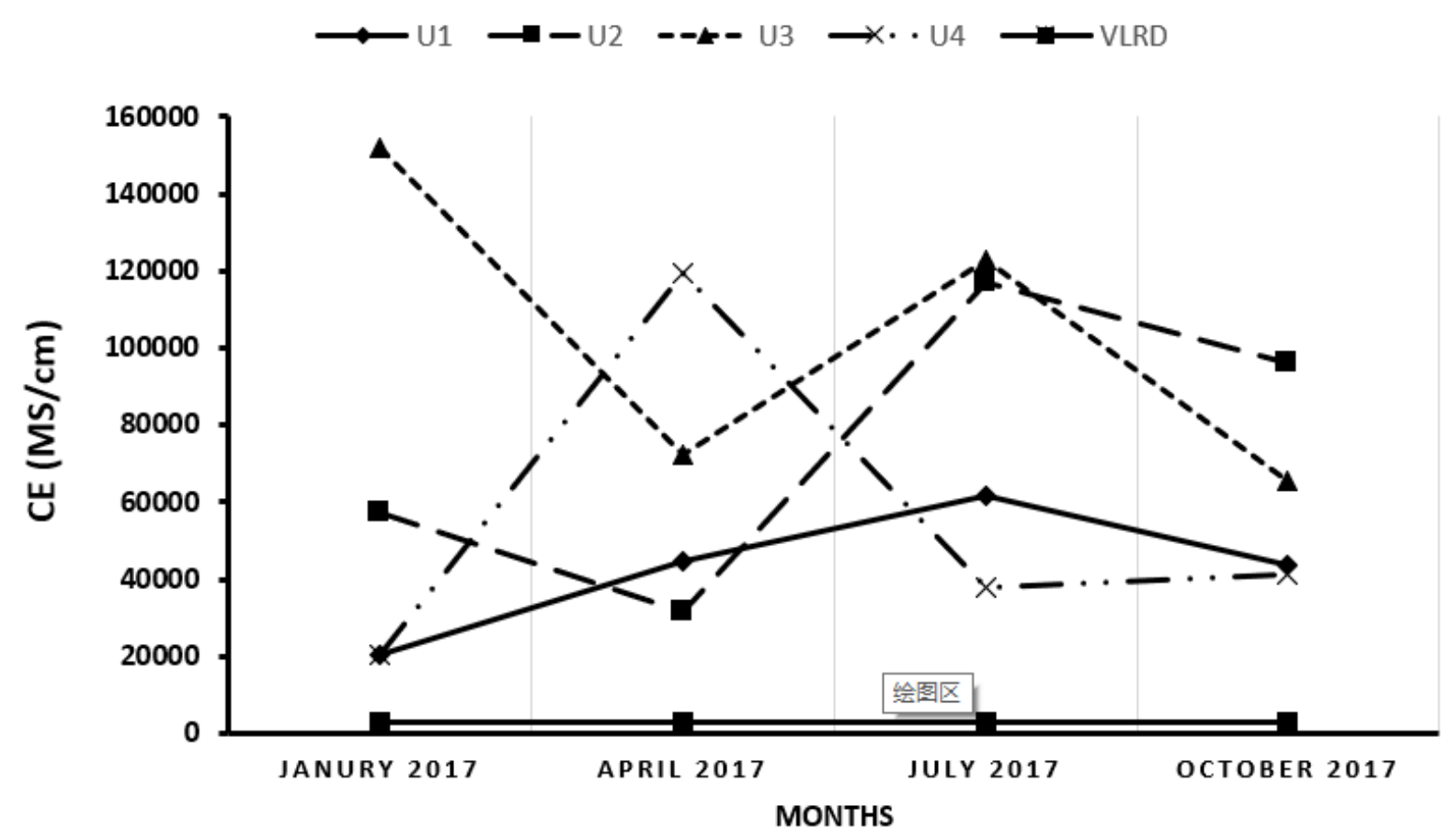

Figure 5. Evolution of the electrical conductivity of the studied discharges

\subsection{Particulate Pollution TSS ( $\mathrm{mg} / \mathrm{L})$}

As in most processing industries, seafood processing operations produce wastewater containing a significant amount of colloidal and particulate contaminants. Figure 6 shows the levels in TSS of the discharges studied.

These TSS represent the mass of all decantable and non-settling particles whether organic or mineral carried by water. For the industrial wastewater studied, the average values vary between $468 \mathrm{mg} / \mathrm{L}$ at unit 4 and $5840 \mathrm{mg} / \mathrm{L}$ at unit 3. The peak of the TSS $11020 \mathrm{mg} / \mathrm{L}$ is recorded during the companion from July to unit 2 . It may be due to intensive production related to an accidental TSS load (Figure 6). In fact, the discards of fish canned units are generally loaded with TSS(Cristóvão, Botelho, Martins, Loureiro, \& Boaventura, 2015).These fine particles in suspension have a detrimental mechanical effect by sediment formation and a screen preventing the good penetration of light.

All TSS levels in the four units are well above the set limit (Morocco's Official Gazette, $\mathrm{N}^{\circ}$. 5062, the standards of direct and indirect discharges, 2002). These high levels of TSS can prevent the penetration of light into the water, decrease the dissolved oxygen content and hinder the development of aquatic life. Compared to other industrial units, the average levels of TSS are higher (El Ghammat \& Temsamani, 2017). 


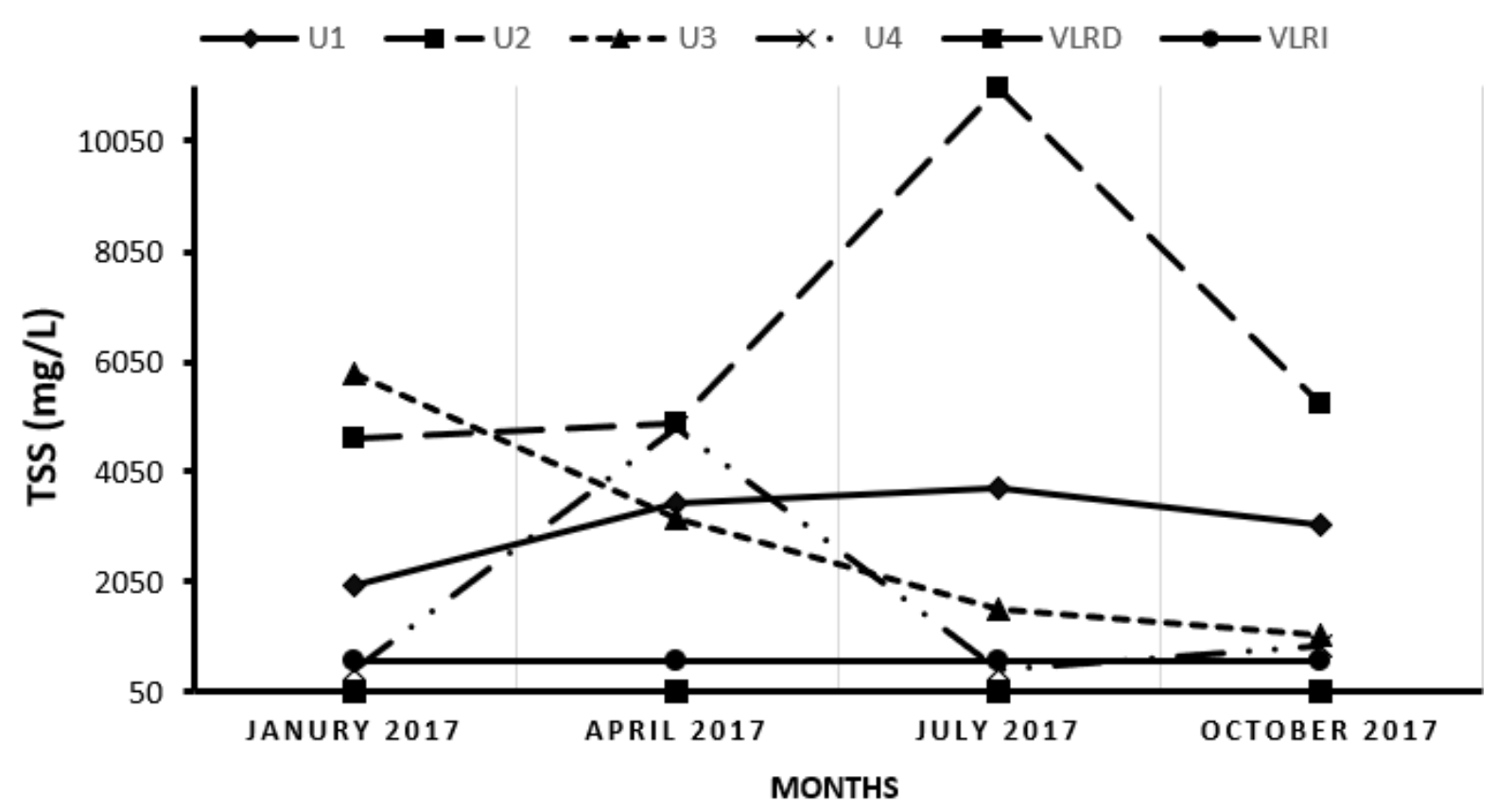

Figure 6. Evolution of the suspended matter content of the studied releases

\subsection{The Oxidizable Pollution}

Oxidizable pollution is due to organic substances that degrade by consuming dissolved oxygen in the water, which has a direct impact on aquatic life. The importance of this pollution is estimated by the measurements of the COD and the BOD5 which correspond to the quantity of oxygen necessary for the degradation of the oxidizable and organic material respectively by chemical and biological processes. The constituent elements of this pollution are nitrogen, phosphorus and carbon.

\subsubsection{Chemical Oxygen Demand (COD)}

The COD values in the wastewater studied show very large fluctuations (Figure 7). They range from $4770 \mathrm{mg} \mathrm{O}_{2} / \mathrm{L}$ as the lowest value recorded in January at unit 1 and $22780 \mathrm{mg}$ $\mathrm{O}_{2} / \mathrm{L}$ as the highest value recorded in October at unit 2 with an average of $10557 \mathrm{mg} \mathrm{O} / \mathrm{L}$. This is in direct relation to the pollutants that exist in each industrial unit. Compared with current regulatory requirements, the COD values are high (Morocco's Official Gazette, $\mathrm{N}^{\circ}$. 5062 ,the standards of direct and indirect discharges, 2002). 


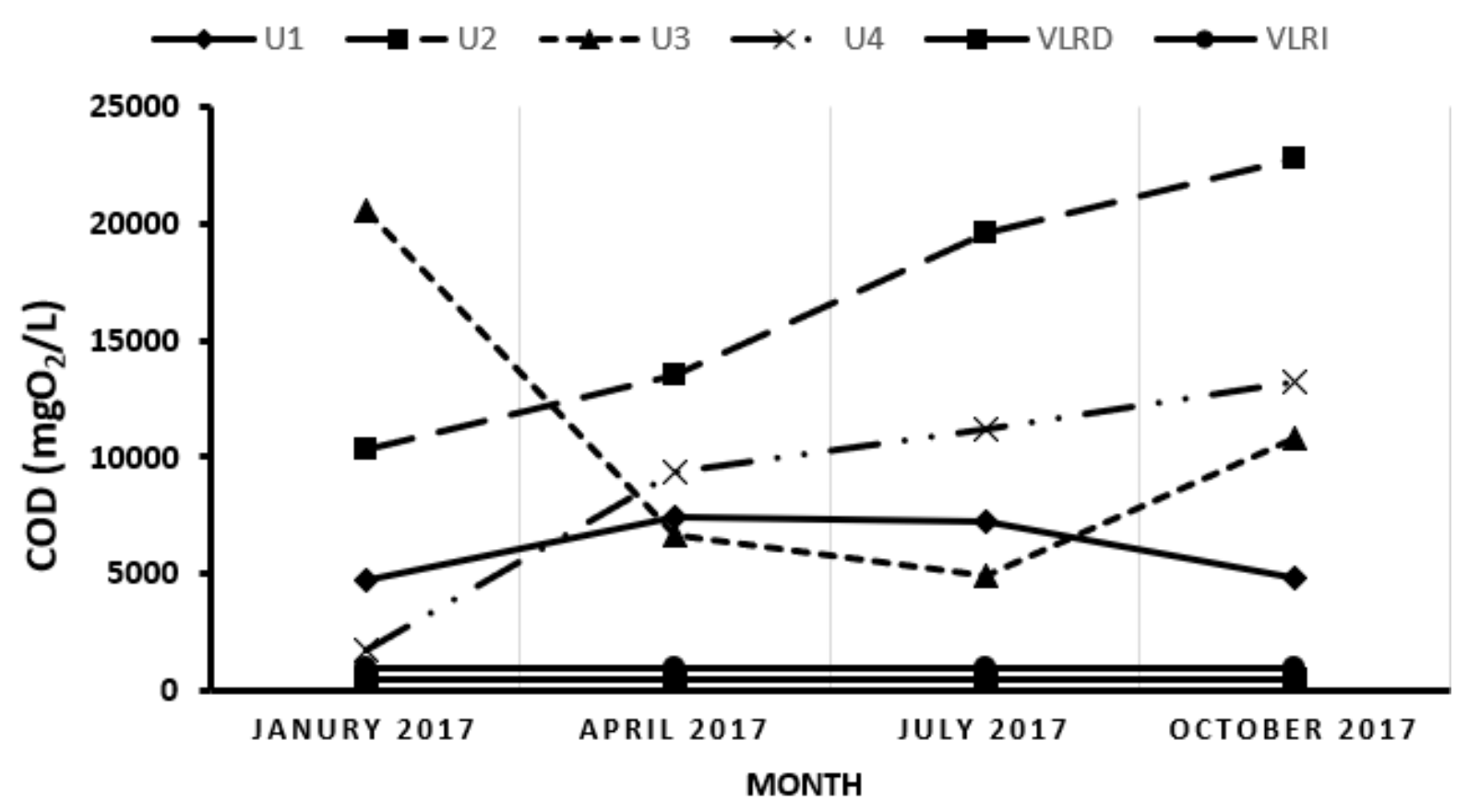

Figure 7. Evolution of the COD of the studied releases

\subsubsection{Biochemical Oxygen Demand (BOD5)}

The values of BOD5 evolve relatively similarly to that of COD. On average, they reach 4877 $\mathrm{mg} \mathrm{O} / \mathrm{L}$ with a minimum of $766 \mathrm{mg} \mathrm{O}_{2} / \mathrm{L}$ observed in January in unit 4 and a maximum of $8920 \mathrm{mg} \mathrm{O} / \mathrm{L}$ in October at unit 4 levels (Figure 8). The different $\mathrm{BOD}_{5}$ values do not comply with the maximum limit of $100 \mathrm{mg} \mathrm{O} / \mathrm{L} \mathrm{BOD} 5$ stipulated by the Moroccan standards for direct discharges (Morocco's Official Gazette, $\mathrm{N}^{\circ}$. 5062, the standards of direct and indirect discharges, 2002). This difference can be explained by the pollutant load and the activity of each industrial unit. In comparison with other Moroccan industrial units, the BOD5 values remain high (Benyakhlef, Naji, \& Belghyti, 2007). 


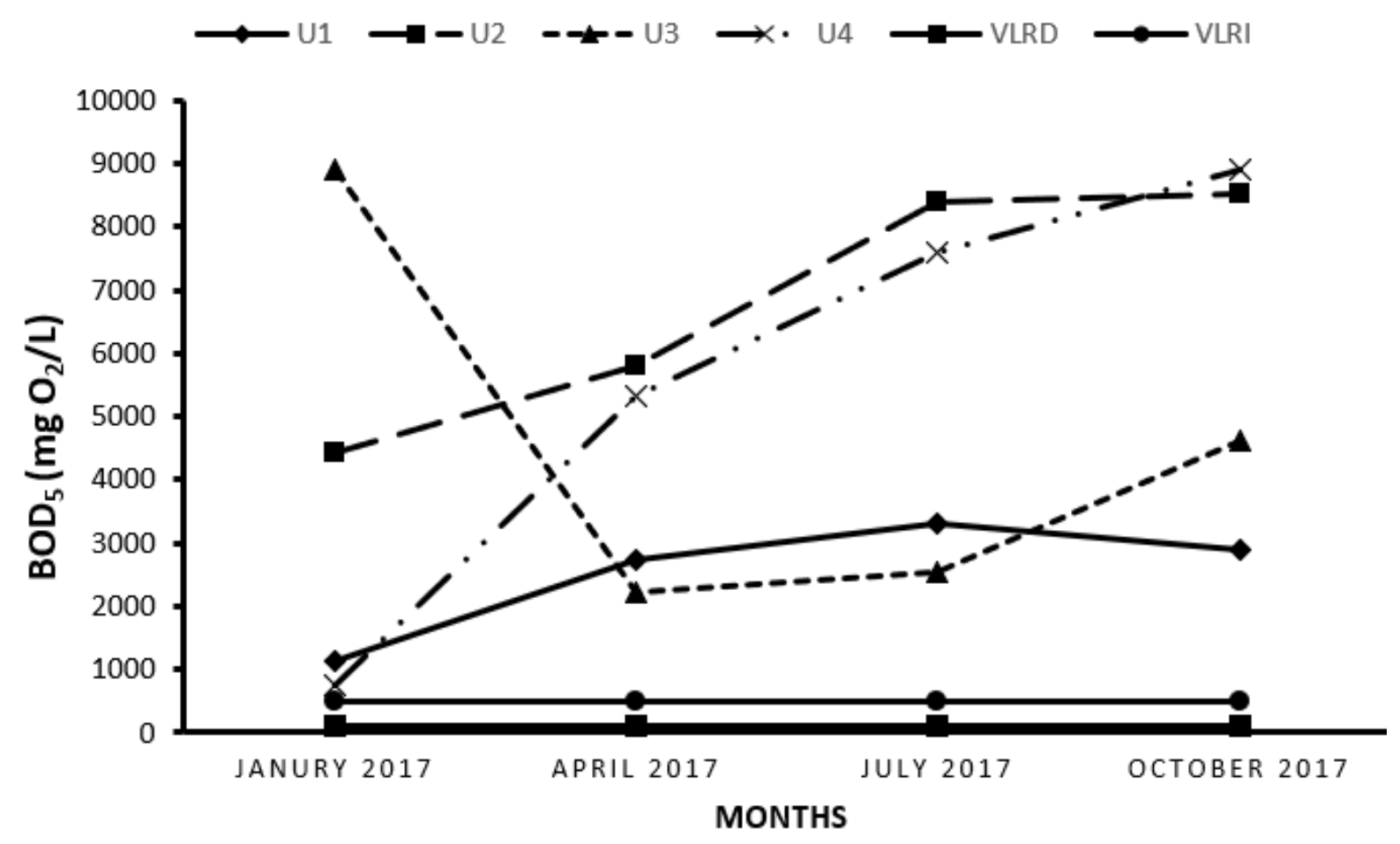

Figure 8. Evolution $\mathrm{BOD}_{5}$ releases of four industrial units

\subsection{Nitrogen and Phosphorus Pollution:}

\subsubsection{Total Nitrogen (NT)}

Total nitrogen is an indicator of environmental pollution and its control makes it possible to monitor the evolution of contamination (Jean Rodier, Legube, Merlet, \& Brunet, 2009). Figure 9 shows the analytical results of this parameter. In our case, the range of variation of NT during the study period fluctuates between a minimum of $180 \mathrm{mg} \mathrm{N} / \mathrm{L}$ and a maximum of $1610 \mathrm{mg} \mathrm{N} / \mathrm{L}$ (Figure 9), with an average of $631 \mathrm{mg} \mathrm{N} / \mathrm{L}$. These grades remain very important and far exceed the limits allowed by the Moroccan standard for direct discharges. These high levels in these units reflect the nitrogen pollution experienced by these agri-food industries. This would lead to excessive growth of algae and additional consumption of dissolved oxygen, resulting in degradation of the aquatic environment, through the phenomenon of eutrophication. 


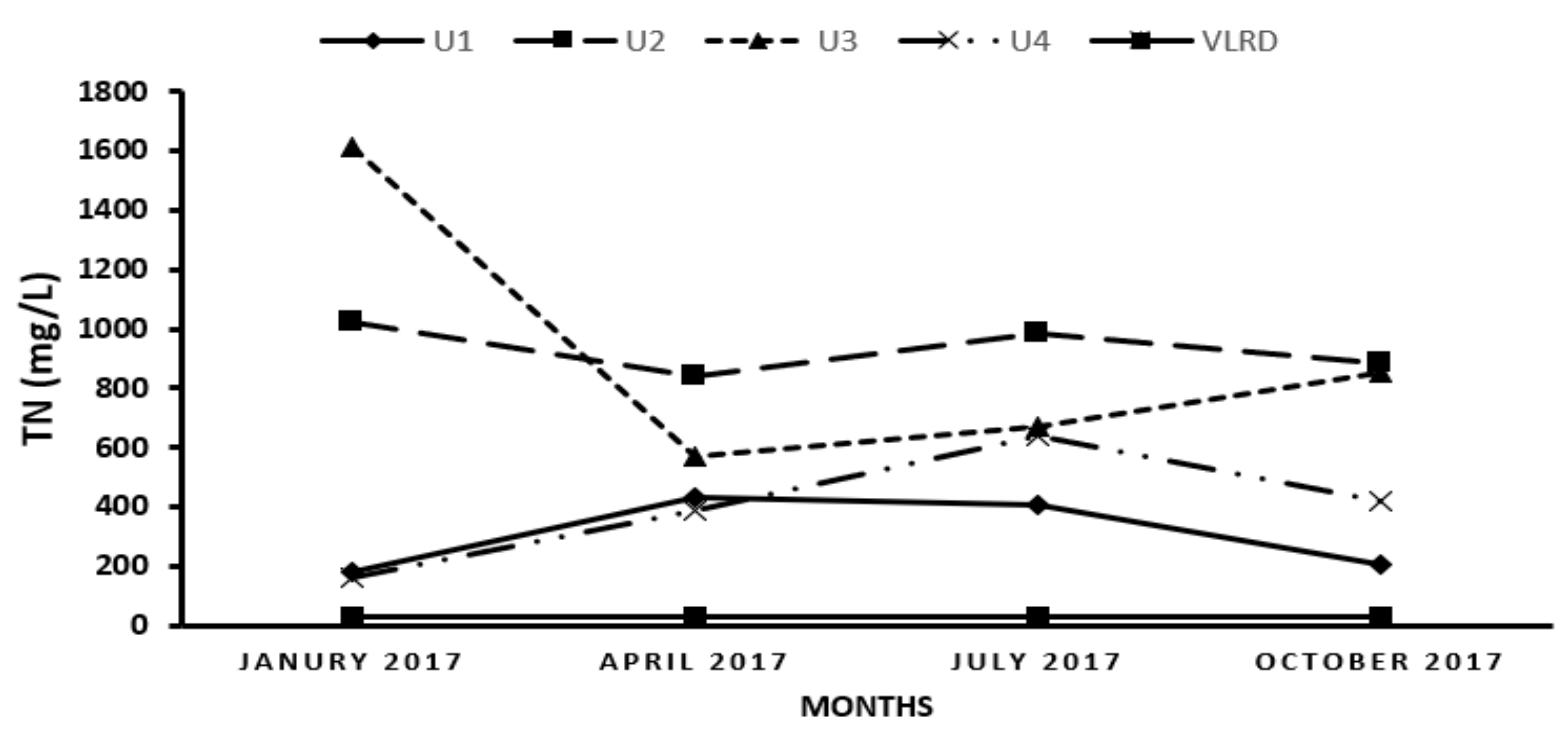

Figure 9. Evolution of the total nitrogen of the discharges studied

\subsubsection{Total Phosphorus (TP)}

Total phosphorus is the sum of phosphorus contained in orthophosphates, polyphosphates and organic phosphorus. The evolution of total phosphorus recalls that observed for total nitrogen. Overall, the levels are very high (Figure 10) at the level of the discharges of the studied units. They range from $19 \mathrm{mg} \mathrm{P} / \mathrm{L}$ at unit 4 and $168 \mathrm{mg} \mathrm{P} / \mathrm{L}$ at unit 2 in January. All the wastewater studied is charged with phosphorus. For unit 2, all values exceed 12 times the normal limit value (Morocco's Official Gazette, $\mathrm{N}^{\circ}$. 5062, the standards of direct and indirect discharges, 2002). Moreover, excess total phosphorus can cause disturbances in the coastal environment (Barroin, 2003).

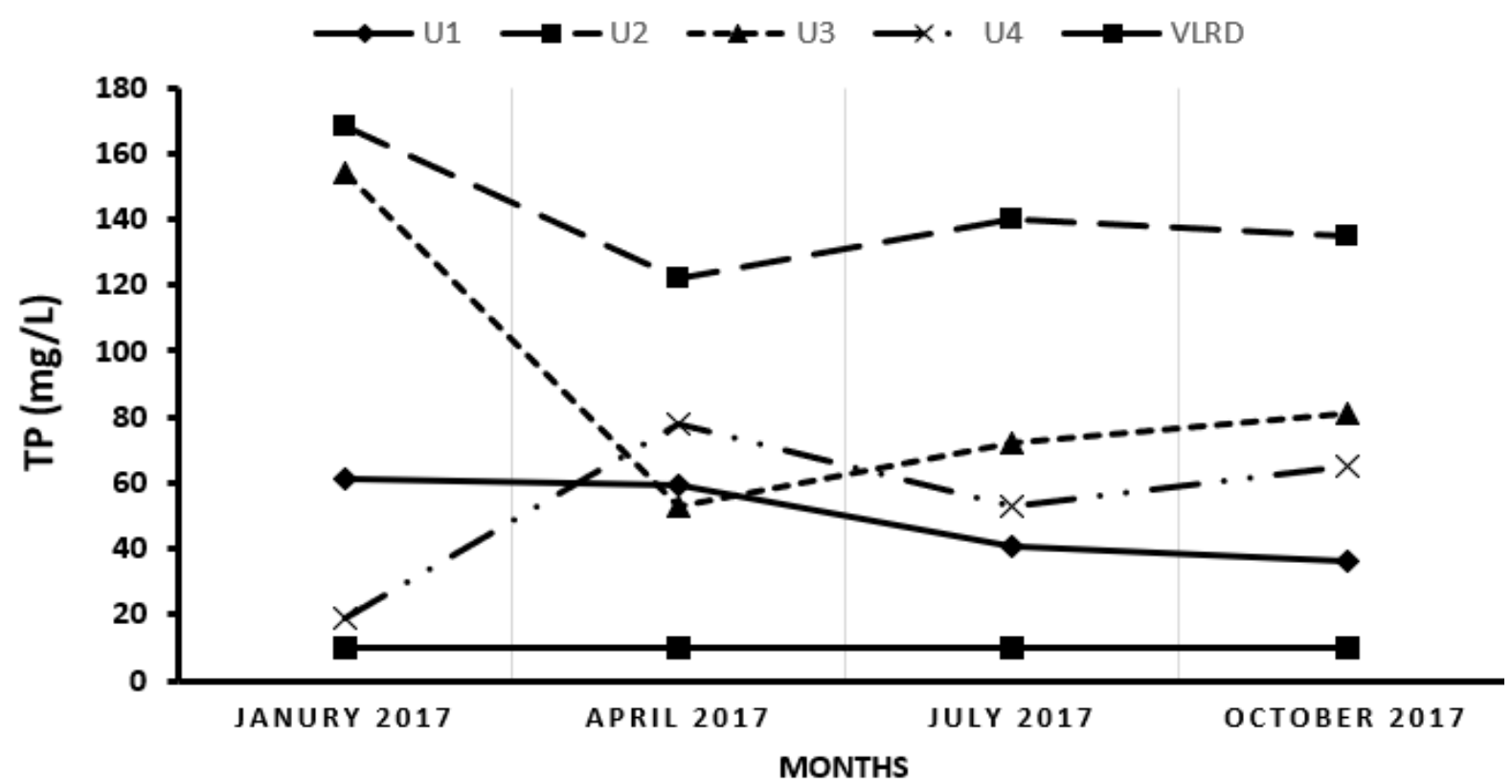

Figure 10. Evolution of the total phosphorus of the studied discharges 


\section{Macrothink}

\subsection{Chlorides, Oils and Fats}

\subsubsection{Chloride}

Figure 11 shows the chloride levels of the wastewater studied. The quantities of chloride in wastewater in the four industrial units of Anza ranged from $12638 \mathrm{mg} / \mathrm{L}$ in the January release of unit 1 to $50410 \mathrm{mg} / \mathrm{L}$ in January at the level of Unit 3 with an average concentration of $25749 \mathrm{mg} / \mathrm{L}$ during the analysis conducted in 2017.

These high levels, which highlight the high values of electrical conductivity, represent a sign of strong mineralization characterizing the releases of canned and semi-conserved fish activities. This is mainly because fish processing plants use large amounts of salt for storage and brine. These brine waters are a major source of pollution (Brodersen, 1971).

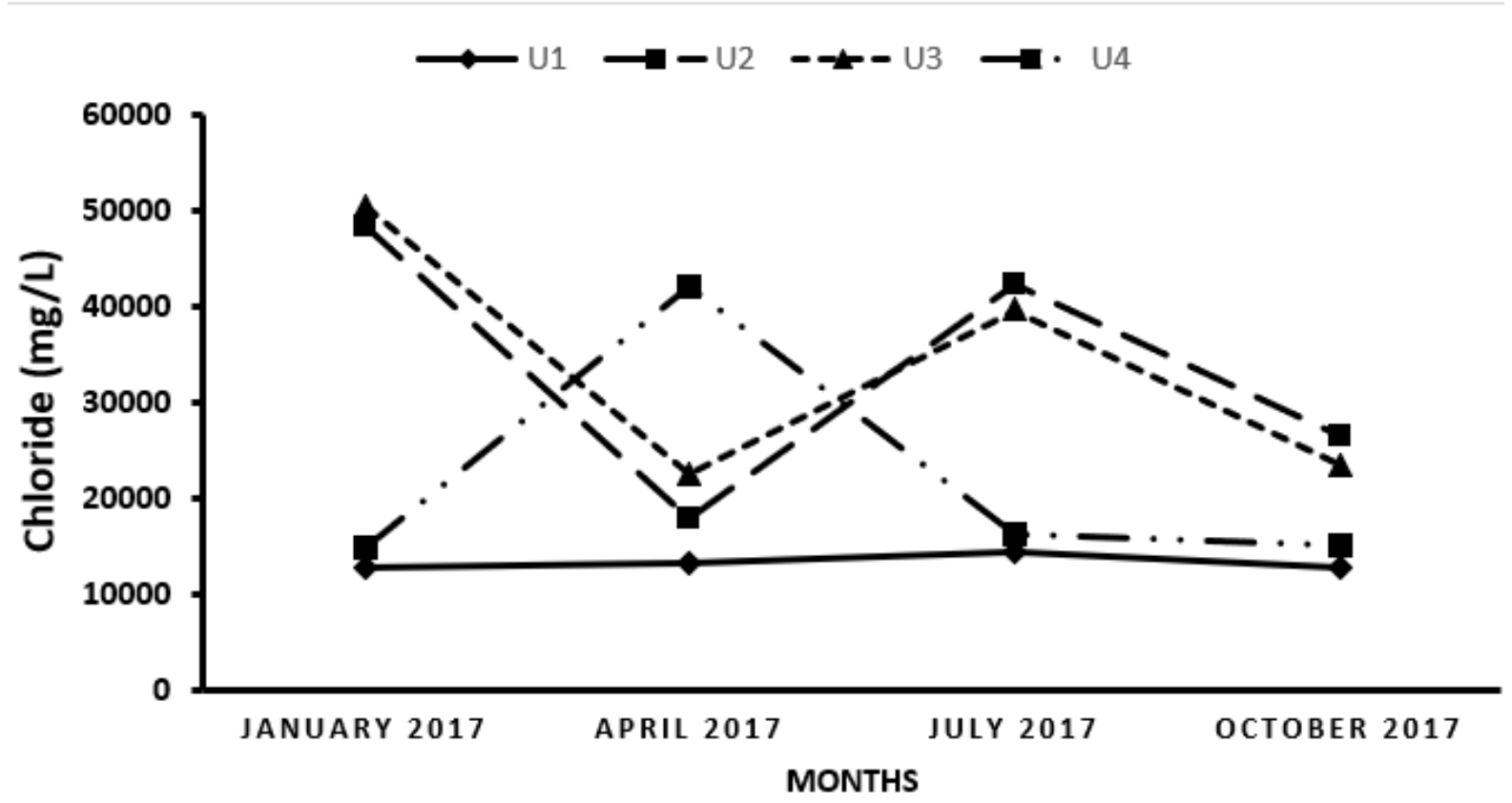

Figure 11. Evolution of the chloride of the discharges studied

\subsubsection{Oils and Fats}

The identification of the origin of the oils and greases is of great utility in the design of the purification works as well as in the detection of the sources of pollution. The oils prevent the supply of oxygen and thus promote the development of anaerobic conditions (Czysz, Denne, \& Rump, 1990). According to the analysis of the results obtained during the samplings, the waste oil and grease levels fluctuate considerably and vary between a minimum of $364 \mathrm{mg} / \mathrm{L}$ (U4) and a maximum of $3843 \mathrm{mg} / \mathrm{L}$ (U2) (Figure 12), an overall average of $2192 \mathrm{mg} / \mathrm{L}$. This average value exceeds 73 times the allowed standard of $30 \mathrm{mg} / \mathrm{L}$ for direct release into the natural environment (Morocco's Official Gazette, $\mathrm{N}^{\circ}$. 5062, the standards of direct and indirect discharges, 2002). 


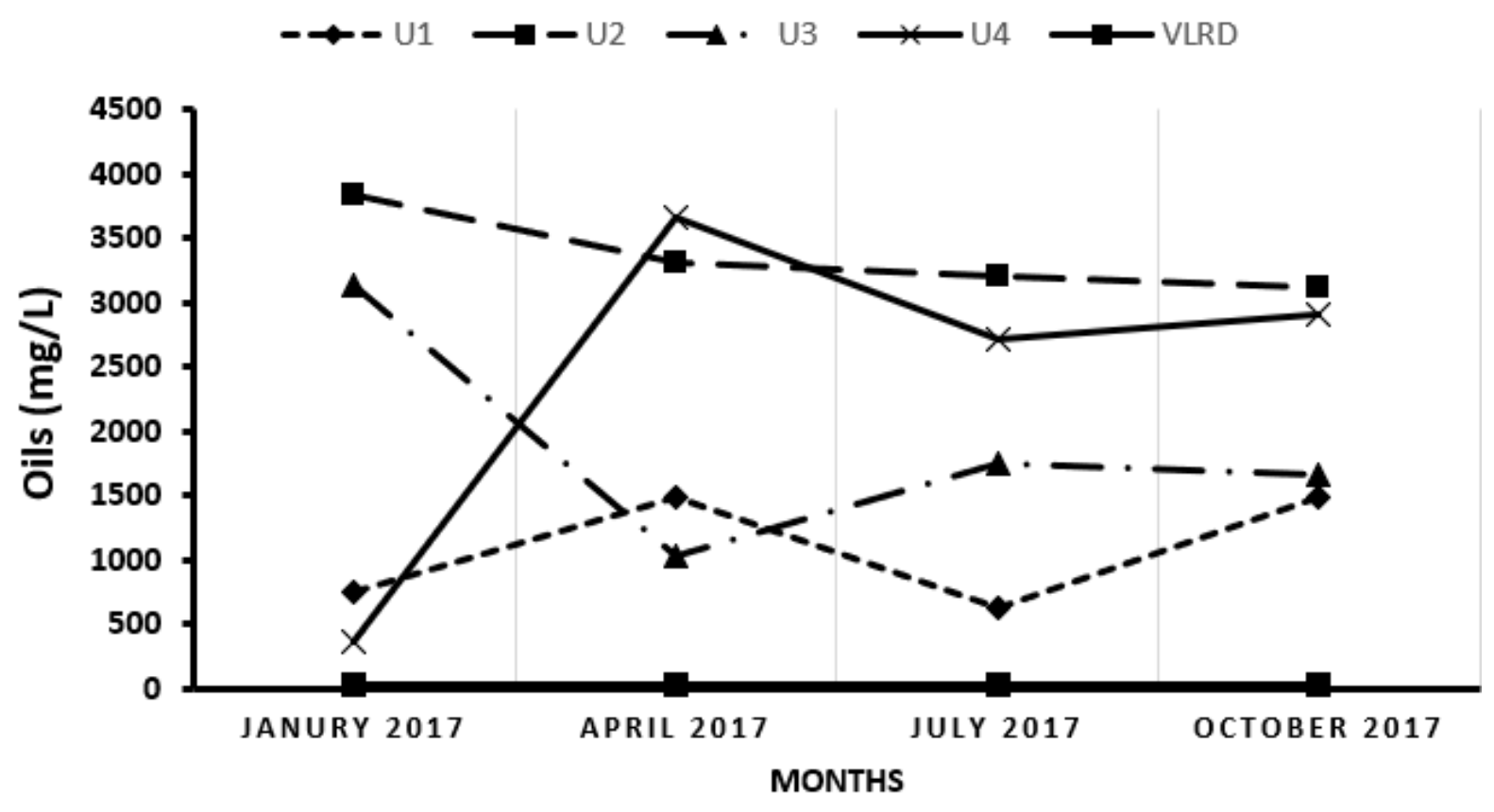

Figure 12. Evolution of the oils and fats of the discharges studied

\subsection{Assessment of Organic Pollution of Industrial Wastewater}

The calculation of the ratios $\mathrm{COD} / \mathrm{BOD}_{5}, \mathrm{BOD}_{5} / \mathrm{COD}$ and TSS / BOD 5 and the estimation of the oxidizable matter $(\mathrm{OM})$ present very important interests. The use of these characterization parameters is a good way to give an image of the degree of pollution of raw industrial effluents and also to optimize the physicochemical parameters of these wastewaters in order to propose a suitable treatment.

\subsubsection{Ratio COD / $\mathrm{BOD}_{5}$}

The COD / BOD5 ratio makes it possible to deduce whether the wastewater discharged directly into the Anza beach has characteristics of domestic wastewater (COD / BOD5 ratio less than 3) (Henze, van Loosdrecht, Ekama, \& Brdjanovic, 2008). The results of this report are an indication of the importance of pollutants with little or no biodegradability. Table 4 presents the minimum and maximum values and the average $\mathrm{COD} / \mathrm{BOD} 5$ ratio for wastewater from the four canned and semi-canned fish plants. 


\section{Macrothink}

Table 4. DCO / BOD5 Ratio of Wastewater from Four Industrial Units

\begin{tabular}{c|c|c|c|c|c|c|c}
\hline & Jan 2017 & April 2017 & July 2017 & October 2017 & Minimum & Maximum & Average \\
\hline $\mathrm{U} 1$ & 4,24 & 2,72 & 2,18 & 1,69 & 1,69 & 4,24 & 2,71 \\
\hline $\mathrm{U} 2$ & 2,34 & 2,32 & 2,33 & 2,67 & 2,32 & 2,67 & 2,42 \\
\hline $\mathrm{U} 3$ & 2,31 & 3,00 & 1,96 & 2,35 & 1,96 & 3,00 & 2,41 \\
\hline $\mathrm{U} 4$ & 2,25 & 1,76 & 1,48 & 1,48 & 1,48 & 2,25 & 1,74 \\
\hline
\end{tabular}

It shows an average of the ratio COD / BOD 5 which varies between 1.74 and 2.71, hence less than 3, meaning that these liquid effluents are rich in organic matter and easily biodegradable (Boughou, Majdy, Cherkaoui, Khamar, \& Nounah, 2006). With the exception of the value recorded in January for Unit 1 , the review of this report highlights the biodegradability of industrial wastewater studied to which a biological treatment appears suitable (Chowdhury, Viraraghavan, \& Srinivasan, 2010).

\subsubsection{Ratio $\mathrm{DBO}_{5} / \mathrm{COD}$}

Table 5 summarizes the $\mathrm{DBO}_{5}$ / COD ratio of wastewater from the four industrial units. This ratio is relatively high and ranges from 0.24 to 0.68 .

This is the general case for discharges loaded with organic matter. This organic load makes this wastewater unstable and will evolve quickly to digested forms with the risk of odor release. In fact, the wastewater from these industrial units is predominantly organic.

Table 5. DBO5 / DCO Ratio of Wastewater from Four Industrial Units

\begin{tabular}{l|c|c|c|c|c|c|c}
\hline & Jan 2017 & April 2017 & July 2017 & October 2017 & Minimum & Maximum & Average \\
\hline $\mathrm{U} 1$ & 0,24 & 0,37 & 0,46 & 0,59 & 0,24 & 0,59 & 0,42 \\
\hline $\mathrm{U} 2$ & 0,43 & 0,43 & 0,43 & 0,37 & 0,37 & 0,43 & 0,42 \\
\hline $\mathrm{U} 3$ & 0,43 & 0,33 & 0,51 & 0,43 & 0,33 & 0,51 & 0,43 \\
\hline $\mathrm{U} 4$ & 0,44 & 0,57 & 0,68 & 0,68 & 0,44 & 0,68 & 0,59 \\
\hline
\end{tabular}

\subsubsection{TSS / BOD5 Ratio and Oxidizable Materials}

The calculation of the TSS / $\mathrm{BOD}_{5}$ ratio of the different wastewater samples gave the results shown in Table 6. The TSS / BOD5 ratio is high, which confirms that the wastewater analyzed is heavily loaded with organic matter (Table 6). 


\section{MlMacrothink}

Table 6. TSS / $\mathrm{BOD}_{5}$ ratio of wastewater from the four industrial units

\begin{tabular}{l|c|c|c|c|c|c|c}
\hline & Jan 2017 & April 2017 & July 2017 & October 2017 & Minimum & Maximum & Average \\
\hline $\mathrm{U} 1$ & 1,78 & 1,28 & 1,14 & 1,07 & 1,07 & 1,78 & 1,32 \\
\hline $\mathrm{U} 2$ & 1,05 & 0,85 & 1,31 & 0,62 & 0,62 & 1,31 & 0,96 \\
\hline $\mathrm{U} 3$ & 0,66 & 1,44 & 0,62 & 0,24 & 0,24 & 1,44 & 0,74 \\
\hline $\mathrm{U} 4$ & 0,63 & 0,91 & 0,06 & 0,10 & 0,06 & 0,91 & 0,43 \\
\hline
\end{tabular}

This result obtained is confirmed by the estimate of the oxidizable substance, which is of the order of $6770 \mathrm{mg} / \mathrm{L}$ with a ratio of TSS / BOD 5 which varies from 0.06 to $1.78 \mathrm{mg} / \mathrm{L}$. In addition, the $\mathrm{COD} / \mathrm{BOD}_{5}$ ratio is low, which allows us to deduce that the organic matter load in the wastewater in the four units of the Anza industrial zone is easily biodegradable.

\section{Conclusion}

This study allowed us to evaluate the quantity and physicochemical quality of wastewater from four industrial canned and semi-preserved fish plants. It shows that these liquid discharges have a variable composition from one season to another. The monitoring during the year 2017 has recorded significant loads of particulate pollution, oxidizable, nitrogen and phosphorus pollution. These industrial effluents have a very high salinity and values of the major pollution parameters that exceed relative to the general limit values of the direct and indirect discharges in the receiving environment. This high pollutant load represents a risk of environmental pollution especially for the Anza area, hence, the need for treatment of this raw wastewater. At the end of the assessment of the degree of organic pollution, it can be noted that all the parameters studied (in particular BOD5, COD and TSS) locate the wastewater analyzed in the high concentration slice. Examination of the $\mathrm{COD} / \mathrm{BOD}_{5}$ ratio highlights the biodegradability of Anza industrial wastewater. For these complex hypersaline effluents, treatment using a combination of physico-chemical and biological processes is proving to be an effective alternative for valorizing these discharges and minimizing their negative impact on the littoral.

\section{References}

AFNOR standard (NF T90-023). Testing water: determination of orthophosphates, hydrolysable phosphates and total phosphorus (spectrophotometric method).

AFNOR standard (NF T90-105-2). Water quality- determination of suspended solids method by centrifugation.

Ait Taleb, A., ElMaimouni, L., Laknifli, A., \& El Hammadi, A. (2010). Quantification des COV aldéhydes dans l'air extérieur du site industriel Anza (Nord ouest d'Agadir) Aldehydes VOCs Quantification in ambient air of Anza industrial site (North west of Agadir). 
Al-Juhaishi, M. (2018). Caractérisation et impact de la pollution dans les rejets urbains par temps de pluie (RUTP) sur des bassins versants de l'agglomération Orléanaise. 193.

Barroin, G. (2003). Phosphore, azote et prolifération des végétaux aquatiques.

Benyakhlef, M., Naji, S., \& Belghyti, D. (2007). Caractérisation des rejets liquides d'une conserverie de poissons. Bull. Soc. Pharm. Bordeaux, 146, 225-234. https://www.socpharmbordeaux.asso.fr/pdf/pdf-146/146-225-234.pdf

Bliefert, C., \& Perraud, R. (2007). Chimie de l'environnement: Air, eau, sols, déchets. De Boeck Superieur.

Boughou, N., Majdy, I., Cherkaoui, E., Khamar, M., \& Nounah, A. (2006). Physico-chemical characterization of wastewater from slaughterhouse: case of rabat in morocco. ARPN. Journal of Agricultural and Biological Science, 13(2), 19-24. http://www.arpnjournals.org/jabs/research_papers/rp_2018/jabs_0218_890.pdf

Brodersen, K. (1971). Characterization of Fish Processing Plant Effluents A Study of the Waste Characteristics of Fish Processing Plants Located in the Maritime Region. Report prepared by Department of Environment, Government of Canada.

Chowdhury, P., Viraraghavan, T., \& Srinivasan, A. (2010). Biological treatment processes for fish processing wastewater-A review. Bioresource technology, 101(2), 439-449. https://doi.org/10.1016/j.biortech.2009.08.065

Colic, M., Morse, W., Hicks, J., Lechter, A., \& Miller, J. D. (2007). Case study: Fish processing plant wastewater treatment. Proceedings of the Water Environment Federation, 2007(7), 1-27. https://doi.org/10.2175/193317708X293133

Cristóvão, R. O., Botelho, C. M., Martins, R. J., Loureiro, J. M., \& Boaventura, R. A. (2015). Fish canning industry wastewater treatment for water reuse-a case study. Journal of Cleaner Production, 87, 603-612. https://doi.org/10.1016/j.jclepro.2014.10.076

Cristóvão, R. O., Pinto, V. M., Gonçalves, A., Martins, R. J., Loureiro, J. M., \& Boaventura, R. A. (2016). Fish canning industry wastewater variability assessment using multivariate statistical methods. Process Safety and Environmental Protection, 102, 263-276. https://doi.org/10.1016/j.psep.2016.03.016

Cristovão, R., Botelho, C., Martins, R., \& Boaventura, R. (2012). Chemical and biological treatment of fish canning wastewaters. International Journal of Bioscience, Biochemistry and Bioinformatics, 2, 237-242. https://doi.org/10.7763/IJBBB.2012.V2.108

Czysz, W., Denne, A., \& Rump, H. (1990). Technologie des eaux résiduaires : Production, collecte, traitement et analyse des eaux résiduaires. Springer-Verl. Paris etc.

Dramais, G., Camenen, B., \& Le Coz, J. (2018). Comparaison de methodes pour la mesure des matieres en suspension dans les cours d'eau, en présence de sable. La Houille Blanche, (5-6), 96-105. https://doi.org/10.1051/lhb/2018056 
Ebina, J., Tsutsui, T., \& Shirai, T. (1983). Simultaneous determination of total nitrogen and total phosphorus in water using peroxodisulfate oxidation. Water research, 17(12), 1721-1726. https://doi.org/10.1016/0043-1354(83)90192-6

El Ghammat, A., \& Temsamani, K. R. (2017). Etude de Caractérisation physico-chimique des eaux usées en vue de la mise en oeuvre d'un traitement adéquat: Cas de la zone industrielle de Tétouan/Study of Physico-Chemical Characteristics of Waste Water of an Industrial Zone of Tetouan. International Journal of Innovation and Applied Studies, 20(3), 840.

Eymery, F., Choubert, J. M., Lepot, B., Gasperi, J., Lachenal, J., \& Coquery, M. (2012). Pratiques d'échantillonnage et de conditionnement en vue de la recherche de micropolluants prioritaires et émergents en assainissement collectif et industriel. Guide technique Aquaref, 85.

Henze, M., van Loosdrecht, M. C., Ekama, G. A., \& Brdjanovic, D. (2008). Biological wastewater treatment. IWA publishing.

Islam, M. S., \& Tanaka, M. (2004). Impacts of pollution on coastal and marine ecosystems including coastal and marine fisheries and approach for management: A review and synthesis. Marine pollution bulletin, 48(7-8), 624-649. https://doi.org/10.1016/j.marpolbul.2003.12.004

Keith, L. (2017). Environmental sampling and analysis: A practical guide. Routledge.

Korkmaz, D. (2001). Precipitation titration: "Determination of Chloride by the Mohr Method". Methods, 2(4).

Lefebvre, O., \& Moletta, R. (2006). Treatment of organic pollution in industrial saline wastewater: A literature review. Water research, 40(20), 3671-3682. https://doi.org/10.1016/j.watres.2006.08.027

Mimouni, R., Ait Alla, A., Anajjar, E., Finance, C., \& Moukrim, A. (2002). Impact of wastewater discharges on the microbiological quality of beaches in the Agadir Bay (Morocco). Journal Europeen d'Hydrologie, 33(1), 115-123.

https://doi.org/10.1051/water/20023301115

Ministry of Environment Morocco's Official Gazette, No. 5062 of 30 Ramadan 1423. Rabat, the standards of direct and indirect discharges. (2002).

Nelson, D., \& Sommers, L. (1973). Determination of Total Nitrogen in Plant Material 1. Agronomy Journal, 65(1), 109-112.

https://doi.org/10.2134/agronj1973.00021962006500010033x

Régie Autonome multi-service d'Agadir RAMSA. (2017). Report activity of industrial discharges in the great Agadir.

Rodier, J., Legube, B., Merlet, N., \& Brunet, R. (2009). L'analyse de l'eau [Water analysis].

Rodier, J., \& Legube, B. (2009). L'analyse de l'eau. Dunod. 


\section{Macrothink}

Aquatic Science and Technology

ISSN 2168-9148 2020, Vol. 8, No. 1

Rodier, J., Legube, B., Merlet, N., \& Brunet, R. (2009). L'analyse de l'eau-9e éd. : Eaux naturelles, eaux résiduaires, eau de mer. Dunod.

Romero, M. T., \& Ferrer, N. (1999). Determination of oil and grease by solid phase extraction and infrared spectroscopy. Analytica Chimica Acta, 395(1-2), 77-84. https://doi.org/10.1016/S0003-2670(99)00326-8

Setti, I., Moukrim, A., Martinez-Urtaza, J., \& Hanoune, A. (2017). Assessment of Microbiological Contamination of Marine Ecosystems: Can we Continue to Limit Ourselves to the Analysis of Fecal Parameters for the Assessment of the Coastal Ecosystems Quality?. International Journal of Scientific Research in Science, Engineering and Technology, 3(7), 370-372. http://ijsrst.com/IJSRST1736133

Sigg, L., Behra, P., \& Stumm, W. (2014). Chimie des milieux aquatiques-5e édition : Cours et exercices corrigés. Dunod.

Standard ISO 15705: (2002) "Water quality-Determination of the chemical oxygen demand index (ST-COD)-Small scale sealed tube method".

\section{Copyrights}

Copyright for this article is retained by the author(s), with first publication rights granted to the journal.

This is an open-access article distributed under the terms and conditions of the Creative Commons Attribution license (http://creativecommons.org/licenses/by/4.0/) 